\title{
Research on Transportation of Health-hazardous Waste
}

\author{
Nijole Batarliene ${ }^{1 \star}$
}

${ }^{1}$ Vilnius Gediminas Technical University, Faculty of Transport Engineering, Department of Logistics and Transport Management, Plytines Street 27, LT-10105 Vilnius, LITHUANIA

*Corresponding Author: nijole.batarliene@vgtu.lt

Citation: Batarliene, N. (2020). Research on Transportation of Health-hazardous Waste. European Journal of Sustainable Development Research, 4(1), em0109. https://doi.org/10.29333/ejosdr/6342

\section{ARTICLE INFO}

Received: 2 Aug. 2019

Revised: 22 Nov. 2019

Accepted: 25 Nov. 2019

\begin{abstract}
The article provides information on transportation of health-hazardous waste. Transport accidents of hazardous waste are frequent and can cause serious injuries in inhabited areas or pollution to the environment. It is very important to distinguish such waste from the general waste stream and correctly transport and handle it. For qualitative risk assessment and mitigation planning, consequence calculations are necessary. Transportation of the hazardous waste has a major impact on road traffic and safety. Therefore, it is very important to define all elements of the safe system and apply the concept of "green logistics". The aim of this article is to analyse the peculiarities of health hazards, its transportation characteristics and suggest an algorithm for determining the consignment volume and selecting transportation method in order to prevent damage to the environment and humans and minimize the risks. The scope of article is safe and sustainable transportation of hazardous waste. The article reports the results of the methodology to determine an optimal consignment volume and transportation methods, where the optimality criteria is the general storage and transportation costs is suggested. The algorithm enables to optimally determine an average number of vehicles in accordance with the tonnage of hazardous waste.
\end{abstract}

Keywords: accidents, hazardous waste, transportation, green logistics, algorithm, risk factors, methodology, requirements

\section{INTRODUCTION}

Development of Transport System is linked to the concept of "green logistics". It is the assurance of the well-being of present and future generations that have effects on the free movement of goods, energy consumption, environment, human health, safety and comfort. Therefore, development of transport must include issues of the reduction of the negative impact on the environment.

Reducing pollution from road vehicles and associated negative impact on the environment and human health is one of the most relevant questions in environmental policy of each country.

In order to preserve nature and the environment for future generations, to halt the loss of biodiversity and to protect the soil, the European Union Member States are committed to prevent damage and should damage is caused, to remedy it. Therefore, in 2004, Directive on environmental liability with regard to the prevention and remedying of environmental damage was adopted (Report under article...). This directive establishes a framework based on the polluter pays principle to prevent and remedy environmental damage.

Directive on Environmental Liability aims to form a conscious approach and incentives to invest in prevention measures and better environmental practices. All operators are encouraged to assess the risk and take necessary steps to minimize it.

Hazardous waste can be absorbed into the soil, pollute ground water and thus harm the environment and human health. Therefore, it is very important to distinguish such waste from the general waste stream and correctly transport and handle it (utilize).

Problem statement. Carrying goods and waste by road or rail involves the risk of traffic accidents. If the goods and waste are hazardous, there is also the risk of incidents, such as spillage, leading to hazards such as fire, explosion, chemical burn or environmental damage. Road or railway transportation of hazardous goods and hazardous waste is characterised by wide numbers of different fields, which are reflected in many professional and scientific areas. In general, the most important impact is determined by the global - European and national legislation. National characteristics of economic sectors, existing transportation technology and other local aspect are also important. It is thus important to apply the concept of "green logistics", define elements of traffic safety and distinguish the most relevant characteristics in the system of hazardous waste transportation. 
The aim of the article - to analyse the peculiarities of health hazards, its transportation characteristics and suggest an algorithm for determining the consignment volume and selecting transportation method in order to prevent damage to the environment and humans and minimize the risks.

\section{PECULIARITIES OF HAZARDOUS WASTE}

Hazardous waste comprises a separate waste group. According to the levels of hazardousness and handling specifics, the following streams are distinguished:

- petroleum waste products;

- petroleum-contaminated waste;

- hazardous vehicle waste;

- waste contaminated with toxic heavy metals;

- chemical waste;

- medical waste.

Household hazardous waste - is a non-industrial waste generated in the households, small enterprises, institutions or organizations, legal entities and offices. These may include: primary cells, batteries, outdated medicines, household chemicals, waste of varnishes, paints, thinners, chemicals and contaminated packaging materials, used oil, oil filters and other petroleum waste products, mercury-containing waste, used tires and other hazardous waste (Landrigan, 2004).

Slack, Gronow and Voulvoulis (2004) maintain that "household hazardous waste includes waste containing hazardous substances originating from domestic sources". Recently, household hazardous waste has been on the rise due to ever-increasing solid municipal waste.

Industrial waste is defined as waste generated by manufacturing or industrial processes; remnants, which wholly or partially lost their original properties (chemical or physical). Table 1 provides information on the amounts of the collected health hazards for the period of 2010-2017.

Table 1. Collected health hazards according to separate types in Lithuania (in tonnes)

\begin{tabular}{|c|c|c|c|c|c|c|c|c|}
\hline & 2010 & 2011 & 2012 & 2013 & 2014 & 2015 & 2016 & 2017 \\
\hline Spent solvents & 33 & 68 & 55 & 115 & 124 & 109 & 148 & 160 \\
\hline Acid, alkaline or saline wastes & 3629 & 4723 & 4358 & 4242 & 4820 & 4495 & 4588 & 4958 \\
\hline Used oil & 3989 & 4001 & 3328 & 3379 & 4372 & 5219 & 4802 & 5281 \\
\hline Spent chemical catalysts & 0 & 14 & 28 & 24 & 1 & 426 & 447 & 346 \\
\hline Non-exploitative chemical waste & 630 & 1303 & 801 & 1023 & 1192 & 1637 & 1900 & 2403 \\
\hline Chemical compound waste & 1112 & 343 & 383 & 628 & 516 & 543 & 742 & 1579 \\
\hline Chemical deposits and residues & 45548 & 46311 & 34650 & 45208 & 44407 & 44108 & 43495 & 29821 \\
\hline Infectious health-care waste & 1120 & 883 & 1144 & 1150 & 1266 & 1275 & 1242 & 638 \\
\hline Waste containing polychlorinated biphenyls (PCBS) & 67 & 40 & 32 & 22 & 8 & 11 & 19 & 1244 \\
\hline Motor vehicle declared out of service & 16382 & 21198 & 25010 & 30724 & 32160 & 27442 & 25280 & 13 \\
\hline Discarded electrical and electronic equipment & 2656 & 4022 & 4553 & 4382 & 4406 & 4316 & 4472 & 14 \\
\hline Unused machines and equipment components & 17142 & 17215 & 19251 & 17530 & 17541 & 16865 & 16654 & 26115 \\
\hline Waste from Recycling Process & 10529 & 17846 & 15455 & 15203 & 14577 & 16166 & 14929 & 5544 \\
\hline Asbestos Waste & 4528 & 5045 & 16166 & 14167 & 18179 & 12981 & 9947 & 15074 \\
\hline
\end{tabular}

Source: The Environmental Protection Agency (EPA)

The quantities of hazardous waste are illustrated in Figure 1.

\section{The quantities of hazardous waste}

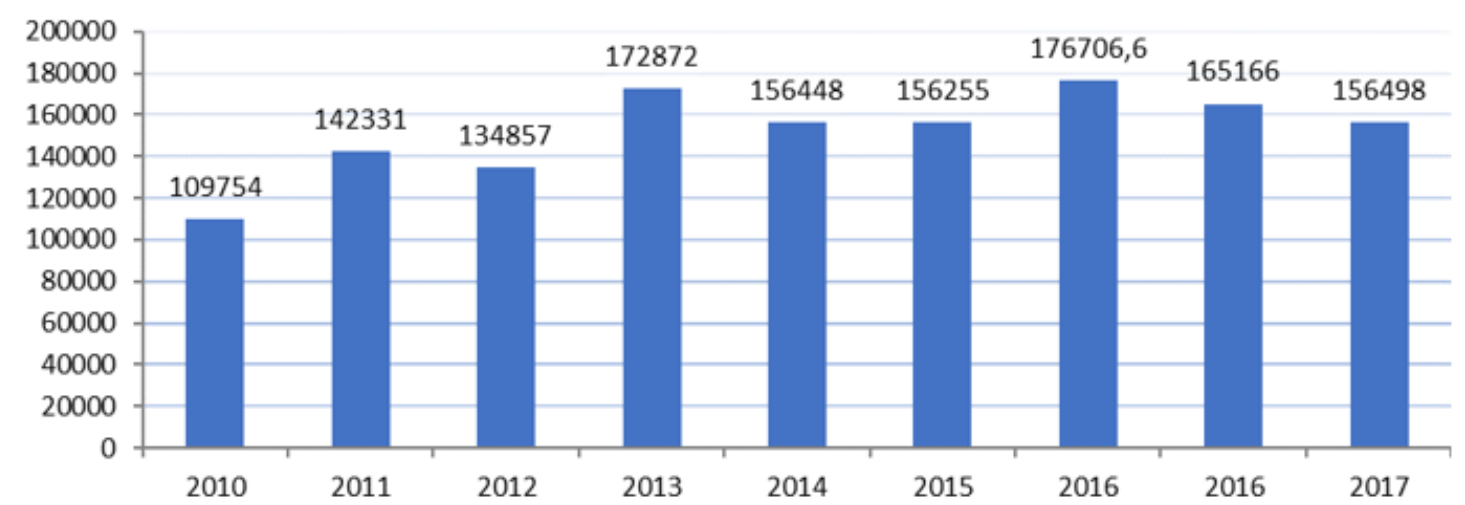

Figure 1. The total quantities of hazardous waste 2010-2017 in Lithuania (in tonnes) (Created by the author based on statistics) 
Table 2. Information on the accidents and remediation processes registered in Lithuania

\begin{tabular}{|c|c|}
\hline $\begin{array}{l}\text { Date of occurrence and/or } \\
\text { discovery of the damage }\end{array}$ & $\begin{array}{l}\text { Outcome of the remediation process: } \\
\text { the types of remedial actions, the costs of remediation }\end{array}$ \\
\hline $\begin{array}{l}\text { Discovery of the damage on } \\
\text { February } 20,2012 .\end{array}$ & $\begin{array}{l}\text { - The state of the environment: no significant risk of adversely affecting human health, contamination level is } \\
\text { below the threshold values set out in the legislation. } \\
\text { - Remedial actions: removal of contaminated soil and decontamination, removal of contaminated water from } \\
\text { water remediation wells. } \\
\text { - The costs of remediation: } 173500 \text { euros. }\end{array}$ \\
\hline $\begin{array}{l}\text { Discovery of the damage on } \\
\text { March 25, } 2009 .\end{array}$ & $\begin{array}{l}\text { - The state of the environment: remedial action is pending. } \\
\text { - Remedial actions: biological treatment of peat layer. } \\
\text { - Preliminary costs of remediation: } 433300 \text { euros. }\end{array}$ \\
\hline $\begin{array}{l}\text { Discovery of the damage on } \\
\text { December } 27,2010 .\end{array}$ & $\begin{array}{l}\text { - The state of the environment: remedial action is pending. } \\
\text { - Remedial actions: removal of contaminated soil, surface and underground biological treatment of soil. } \\
\text { - Preliminary costs of remediation: } 845700 \text { euros. }\end{array}$ \\
\hline $\begin{array}{l}\text { Discovery of the damage on } \\
\text { October } 31,2007 .\end{array}$ & $\begin{array}{l}\text { - The state of the environment: remedial action is pending. } \\
\text { - Remedial actions: collection and removal of oil products from soil and underground water (installation of } \\
\text { remediation wells, removal of contaminated water and decontamination). } \\
\text { - Preliminary costs of remediation: } 25000 \text { euros. }\end{array}$ \\
\hline
\end{tabular}

Table 2 provides information on the accidents registered in Lithuania, as well as the remediation process. Source: The Environmental Protection Agency (EPA) and statistical data.

Global hazardous waste flows and waste management technologies are major sources of environmental litigation. They reflect the political structures and struggles within and between developed and less developed countries (Khoo \& Rau, 2009).

Boulton (2015) states that one of the most dangerous and toxic substances known is spent nuclear fuel. The author suggests that this waste can be recycled into fresh fuel or into materials suitable for weapons-grade.

\section{THE CONCEPT OF GREEN LOGISTICS}

According to scientific literature and works conducted on the sustainable development and logistics, (Cherrett, 2009; GuoChuan, 2010; Harris, 2007; McKinnon, 2010; Palmer, 2010; Rodrigue, 2001; Rodrigue, Slack, \& Comtois, 2001; Srivastava, 2007), it was noted that the concept of "green logistics" is linked to sustainable development in the transport sector. Implementation of the "green logistics" - is the company's ability to carry out its operations considering economic, social and environmental factors while increasing labour efficiency and competitiveness (Bagdonienè et al., 2009; Lowe, 2002; Thiell et al., 2011).

Lithuanian scientists identify "green logistics" as highly energy efficient and less environmentally damaging global logistics system that ensures resource-saving, improves waste disposal, increases labour efficiency and reduces negative impact on the environment (Kutkaitis \& Župerkienè, 2011).

Čiegis and Grunda (2007) claim that logistics operations are carried out in such a way that the environmental pressures, such as road congestion, air pollution, reduction of the fuel consumption and waste minimization are key factors in political decisions. According to Čepinskis and Masteika (2011), green logistics encompasses 4 implementation fields:

1. Distribution: intermodal transport, reverse logistics, alternatives to transport modes (rail, inland waterways, maritime transport);

2. Energy consumption: reduction of energy consumption, reduction of the levels of the pollution, incorporation of the $\mathrm{CO} 2$ reduction levels into companies' operation policies, assessment of the logistic activities to impact the environment.

3. Manufacturing (production): applications of the clean technologies, waste reduction, its processing and management.

4. Raw material mining: sustainable purchase, applications of the less polluting substances, recycling, re-use of the products.

However, the current situation reveals that the concept of "green logistics" is poorly examined and the analysis of practical implementation is insufficient. In addition, there is a lack of business models that meet not only economic but also ecological and social needs of society; no specific measures are proposed (Hoessle, 2013).

It is important to calculate the size of dangerous cargo and waste batches and select transportation methods in transporting of dangerous cargo and hazardous waste. Therefore, algorithm for determination of cargo consignment volume and selection of transportation methods is provided in the following chapter.

\section{ALGORITHM FOR DETERMINATION OF CONSIGNMENT VOLUME OF HEALTH-HAZARDOUS WASTE}

The organization of dangerous cargo (including hazardous waste) under long-term agreements involves determination of the optimal consignment volumes and selection of transportation methods. The costs of transportation reduce in the case of large consignments, however, the costs of storage increases; and in the case of small consignments - vice versa. Algorithm for 
Determination of Consignment Volumes and Selection of Transportation Methods is suggested. Optimality criterion - overall costs for storage and transportation.

Three transportation methods are analysed:

1. Cargo is delivered in accordance with long-term agreements in large batches. Semi-trailers or trucks are used as a means for transportation. Cargo is partially loaded.

2. Cargo is delivered in medium-sized batches that do not fully load semi-trailers or trucks. Transport enterprises are specialized in delivery of medium-sized batches; generally, integrates cargo into large batches in Cargo Points (Waste Storage).

3. Cargo is delivered in small batches (up to $23 \mathrm{~kg}$ ) by integrating cargo into several Cargo Points (Waste Storage).

Signification: $C$ - overall costs; $C_{T}$ - transportation costs; $C_{1}$ - storage costs, thus:

$$
C=C_{T}+C_{1}
$$

Costs for cargo storage are determined in the following way:

$$
C_{1}=P((V / U) * T)
$$

here: $T$ - duration of cargo carriage on the road (in weeks); $U$ - intensity of supply and consumption (one tonne per week); $P$ - price of the cargo (Eur per $1 \mathrm{~kg}$ ); $V$ - costs for cargo storage (Eur per week/per $1 \mathrm{~kg}$ ).

Costs for transporting one kilogram of cargo are determined as follows:

in case of the first transportation method:

$$
C_{T}=F / R, R \leq S
$$

in case of the second and third transportation methods:

$$
C_{T}=F / R+W
$$

here: $F$ - determined costs for the first cargo batch transportation (Eur); $R$-consignment volume; $S$ - vehicle load capacity (kg); $W$ - price for transporting one $\mathrm{kg}$ of cargo irrespective of the consignment volume.

According to (1), (2), (3), (4) expressions (Baublys 2007) it is possible to obtain that overall costs are minimal, if the consignment volume is equal to:

$$
R *=\min (\sqrt{F U / P S})
$$

whereas the costs for transporting one kilogram of cargo are equal to:

$$
C *=\left\{\begin{array}{l}
2 \sqrt{F P R / U}+W+P R T, \\
P R S / U+F / S+W+P R T
\end{array}\right. \text { or }
$$

Figure 2 indicates typical dependencies between general cargo transportation and storage costs and supply intensity.

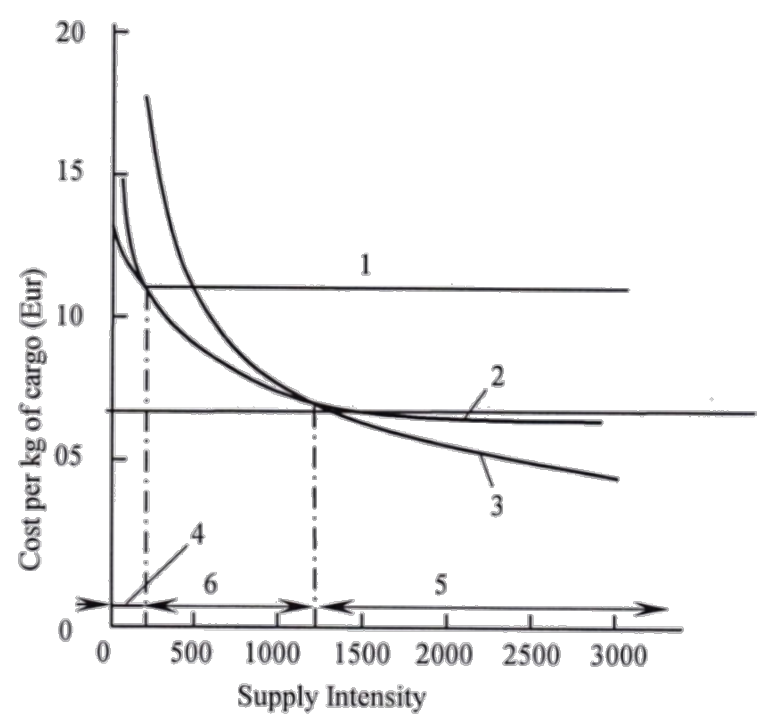

Figure 2. Dependence of one $\mathrm{kg}$ cargo general costs on the supply intensity by diverse cargo transportation methods: 1 - third transportation method; 2 - second transportation method; 3 - first transportation method; 4, 5, 6 - supply intensity, where first, second and third transportation methods are optimal

In Figure 3, the solid line designates the optimal consignment volume dependence on the supply intensity. It can be noted, that under low supply intensity conditions, the third method is the most optimal; under medium supply intensity conditions - the second method, and in the case of high intensity supply conditions - the first cargo transportation method is the most optimal. Dependence of the delivered consignment volume on the supply intensity is not a continuous function. 


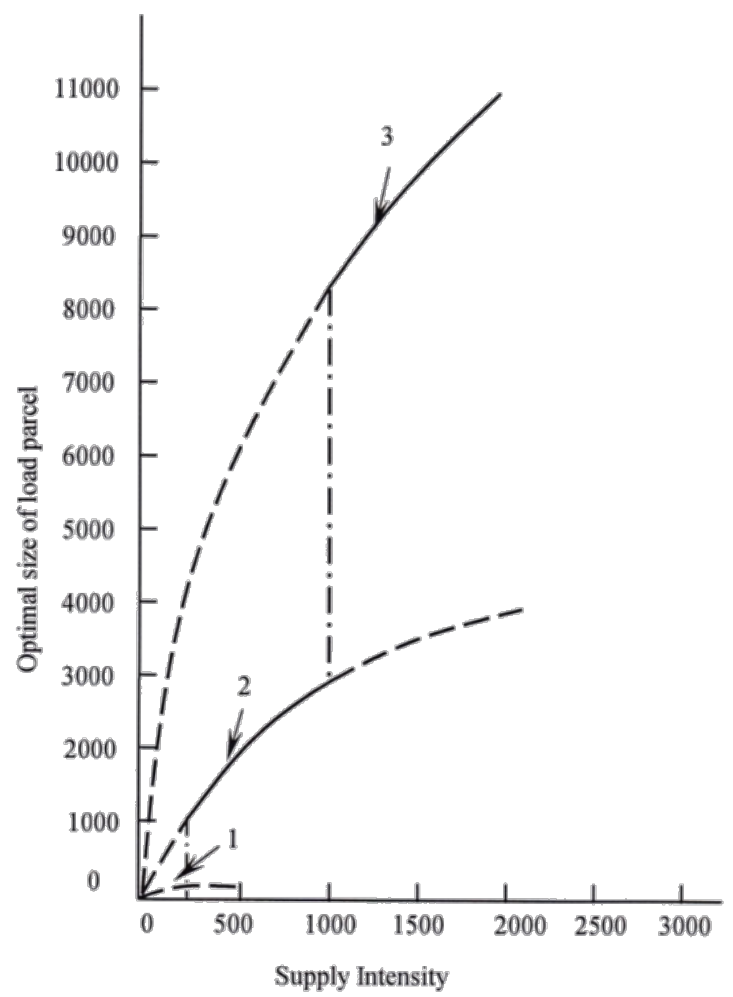

Figure 3. Dependence of the optimal consignment volume on the supply intensity: 1,2 and 3 - first, second and third transportation methods

The obtained values enable to optimize transportation process with initial data.

In order to determine the rational structure of the vehicle fleet and the organizational form of transportation, an analysis of the volume of cargo and the time of specific consignments is required. It is worth to note, that selection of the optimal consignment volume depending on transportation intensity is important in transportation of dangerous cargo and hazardous waste. The analysis of the statistical data indicates that the most frequent transportation method is the one, which is conducted in the small quantities.

Provided models of optimization and simulation synthesis of road transport freight system's topological structure enables the assessment of impact exercised by various structural characteristics on the functioning of the system.

Actions implementing the production capacity of waste management in Lithuania are coordinated by the Ministry of Economy. Health care institutions are responsible for collecting, sorting, packaging, labelling of medical waste and transfer to the authorized waste managers.

\section{REQUIREMENTS RELATED TO THE CARRIAGE OF HAZARDOUS WASTE}

European Parliament and Council of 2006 adopted the provisions of Regulations on the supervision and control of shipments of hazardous waste within, into and out of the European Community. The Regulation applied to shipments of waste between Member States, within the Community or in transit through third countries imported into the Community from third countries.

Depending on the hazardousness of the waste, its handling, shipment and countries of destination, there are the following requirements applicable to the shipment of waste:

- Authorization procedure ("Prior written notification and consent", 4 - Art. 17);

- Simplified procedure ("General information requirements", Art. 18);

- Insurance of the Shipment (in certain cases; waste import into or export from the European Community).

Act of the carriage of dangerous goods and the European agreement "Accord européen relatif au transport international des marchandises dangereuses par route" (ADR) regulate the carriage of dangerous goods by road (European Agreement..., 2013).

Actions implementing the production capacity of waste management in Lithuania are coordinated by the Ministry of Economy. Health care institutions are responsible for collecting, sorting, packaging, labelling of medical waste and transfer to the authorized waste managers. 


\section{RECOMMENDATIONS FOR THE INTERNATIONAL CARRIAGE OF HAZARDOUS WASTES}

Hazardous waste often requires transport to an approved treatment, storage, or disposal facility. Because of potential threats to public safety and the environment, transport is given special attention by governmental agencies. In addition to the occasional accidental spill, hazardous waste has, in the past, been intentionally spilled or abandoned at random locations in a practice known as "midnight dumping." This practice has been greatly curtailed by the enactment of laws that require proper labelling, transport, and tracking of all hazardous wastes.

Hazardous waste is generally transported by truck over public highways. Only a very small amount is transported by rail, and almost none is moved by air or inland waterway. Highway shipment is the most common because road vehicles can gain access to most industrial sites.

Hazardous wastes can be shipped in tank trucks made of steel or aluminum alloy, with capacities up to about 34,000 litres. They also can be containerized and shipped in 200-litre drums. Specifications and standards for cargo tank trucks and shipping containers are included in governmental regulations.

Waste Management Laws govern requirements concerning the transportation of hazardous waste. Stored or transported hazardous waste must be packaged in a way that does not endanger human health and the environment:

- Packaging or containers must be designed and produced in a manner that all of the containing hazardous waste cannot pour, scatter, or otherwise evaporate into the environment.

- Packaging materials must be resistant and not respond to the effects of the containing hazardous waste or its components;

- Packaging or containers and its lids and corks must be firm and hermetic in order not to crack, lose or to come open during the process of transportation;

- Containers with reusable lids and corks must be designed and produced in a manner that involves safe opening and closing; waste and its components do not have any access into the environment.

- All hazardous waste containers and packaging must be labelled (Order of Environment Minister..., 1999).

Corporate actions implementing the production capacity of waste management in Lithuania are coordinated by the Ministry of Economy. Health care institutions are responsible for collecting, sorting, packaging, labelling of medical waste and transfer to the authorized waste managers.

\section{CONCLUSIONS}

1. Theoretically, there are all required institutions in Lithuania responsible for transportation of dangerous cargo, however, there is no unified management system and efficient communication among these institutions. Improvement of dangerous cargo system should involve currently operating institutions.

2. The suggested algorithm enables to optimally determine an average number of vehicles in accordance with the tonnage.

3. The algorithm to determine an optimal consignment volume and transportation methods, where the optimality criteria are the general storage and transportation costs, is suggested.

4. Determination of the requirements does not ensure that all members of cargo transportation process are to comply with it. Therefore, in order to obtain this goal, a concerted and effective operating control mechanism is to be established. In this case, practices of the EU countries are to be considered.

5. Considering the potential risk factors - accident probability, damage to the society, environment and values, ability to quickly liquidate the consequences of an accident, it is thus necessary to establish a list of the prohibited and recommended vehicle routes. However, a periodic assessment of risks and adjustment of the routes should be constantly practiced.

\section{REFERENCES}

Agency for Toxic Substances and Disease Registry. (n.d.). Asbestos: Health Effects. Retrieved on 22 April 2019 from http://www.atsdr.cdc.gov/asbestos/asbestos/health_effects/index.html

Bagdonienè, D., Galbuotienè, A., \& Paulavičienè, E. (2009) Sustainable organizations conceptualization of total quality management basis. (Darnios organizacijos koncepcijos formavimas visuotinès kokybės vadybos pagrindu). Economics and Management (Ekonomika ir vadyba), 14, 1044-1052.

Baublys, A. (2007). Intermodality (Transporto rūšių sq̨veika). https://doi.org/10.3846/1345-M

Boulton, F. (2015). Dangers associated with civil nuclear power programmes: weaponization and nuclear waste. Medicine, Conflict and Survival, 31(2), 100-122. https://doi.org/10.1080/13623699.2015.1062336

Čepinskis, J., \& Masteika, I. (2011). Impacts of Globalization on Green Logistics Centers in Lithuania, Environmental Research. Engineering and Management (Aplinkos tyrimai. Inžinerija ir vadyba), 1(55), 34-42.

Cherrett, T. (2009). Understanding retail supply chains to enable "greener" logistics. Logistics Research Network Annual Conference Cardiff, 9, 105-111. 
Čiegis, R., \& Grunda, R. (2007). Company transformation into a cohesive business process. (¿monès transformavimo į darnią įmonę procesas). Management of Organizations: Systematic Research Organizacijy vadyba: sisteminiai tyrimai, 4, 18-31.

European Agreement concerning the International Carriage of Dangerous freights by road (ADR) and protocol of signature. (2013). United Nations, New York and Geneva. Vol. I, Vol. II.

Feng, S. M., \& Yin, G. Q. (2012). The Classified Management of Transport of Dangerous Goods Section. Applied Mechanics and Materials, 178-181, 1815-1819. https://doi.org/10.4028/www.scientific.net/AMM.178-181.1815

Guo-Chuan, Y. (2010). Constrains and Countermeasures of China's Green Logistics Development. Journal of International Economics and Trade Research Editorial Department China, 02, 5-11.

Harris, I., Naim, M., \& Munford, C. (2007). Global Supply Chains: Developing Skills, Capabilities and Networks - A review of infrastructure modelling for Green Logistics. Logistics Research Network 2007 Conference. Retrieved on 12 April 2019 from http://www.greenlogistics.org.uk

Herbert, R., Moline, J., \& Skloot, G. (2006). The World Trade Center disaster and the health of workers: five-year assessment of a unique medical screening program. Environmental Health Perspectives, 114(12), 1853-1858. https://doi.org/10.1289/ehp.9592

Hoessle, U. (2013) Sustainable Logistics. Best Lessons from the Global Compact (=Walla Walla Solutions Series 2). Seattle. ISBN 9780-9898270-1-0. Retrieved on 24 May 2019 from http://www.wallawallasolutions.com/\#!publications/c243u

Khoo, Su-M., \& Rau, H. (2009). Movements, mobilities and the politics of hazardous waste. Environmental Politics, 18(6), 960-980. https://doi.org/10.1080/09644010903345710

Kutkaitis, A., \& Župerkienè, E. (2011). Sustainable development concept expression in port logistics organizations (Darnaus vystymosi koncepcijos raiška uosto logistinèse organizacijose). Management theory and studies for rural business and infrastructure development, 2(26), 130-136.

Landrigan, P. J., Lioy, P. J., \& Thurston, G. (2004). Health and environmental consequences of the World Trade Center disaster. Environmental Health Perspectives, 112(6), 731-739. https://doi.org/10.1289/ehp.6702

Lowe, D. (2002). Dictionary of Transport and Logistics. Transport Management, 14(1), 1-3.

McKinnon, A., \& Kreie, A. (2010). Adaptive logistics: preparing logistical systems for climate change. Retrieved on 22 April 2019 from http://www.greenlogistics.org/

Order of Environment Minister of the Republic of Lithuania in 1999, 14 July, No. 217 on Waste Rules of Approval (Atlieku tvarkymo taisyklès, patvirtintos Lietuvos Respublikos aplinkos ministro isakymu 1999 m. liepos 14 d.). Retrieved on 20 February 2019 from https://www.e-tar.lt/portal/lt/legalAct/TAR.D3D241048062

Palmer, A., \& Piecyk, M. (2010). Time, cost and CO2 effects of rescheduling freight deliveries. Retrieved on 22 April 2019 from http://www.greenlogistics.org

Report under article 18.1 of directive 2004/35/EC on behalf of the Ministry of Environment of the Republic of Lithuania. Retrieved on 12 May 2019 from http://www.am.It/VI/files/File/ELD_factsheet_LT.pdf

Rodrigue, J.-P. (2001) Green Logistics. Handbook of Logistics and Supply-Chain Management, 340-350. Retrieved from http://worldcat.org/isbn/0080435939

Rodrigue, J.-P., Slack, B., \& Comtois, C. (2001) The Paradoxes of Green Logistics. The Handbook of Logistics and Supply-Chain Management. Pergamon/Elsiever. Retrieved from http://citeseerx.ist.psu.edu/viewdoc/download?doi=10.1.1.620.4904\& rep=rep $1 \&$ type=pdf

Slack, R., Gronow, J., \& Voulvoulis, N. (2004). Hazardous Components of Household Waste. Critical Reviews in Environmental Science and Technology, 34(5), 419-445. https://doi.org/10.1080/10643380490443272

Srivastava, S. K. (2007). Green supply-chain management: A state-of-the-art literature review. International Journal of Management Reviews, 9, 53-80. https://doi.org/10.1111/j.1468-2370.2007.00202.x

The Environmental Protection Agency (EPA). Retrieved on 22 April 2019 from http://atliekos.gamta.lt/cms/ index?rubricld=52fbe286-91c4-4f91-bd54-15a34d4fdf6b

The Ministry of Environment of the Republic of Lithuania. Retrieved on 22 December 2018 from http://www.am.lt/VI/ index.php\#r/891

Thiell, M., Zuluaga, J., Montanez, J., \& van Hoof, B. (2011). Green Logistics - Global Practices and their Implementation in Emerging Markets, Colombia. https://doi.org/10.4018/978-1-60960-531-5.ch018 